\title{
Practolol and bendrofluazide in treatment of hypertension
}

\author{
D. B. Galloway, A. G. Beattie, and J. C. Petrie \\ From Department of Therapeutics and Clinical Pharmacology, University of Aberdeen
}

The value of practolol in the treatment of hypertension has not been clearly established. $A$ double-blind within patient comparison of practolol $400 \mathrm{mg} /$ day, bendrofluazide $5 \mathrm{mg} /$ day, and combined therapy of practolol with bendrofluazide has been carried out in 24 patients with sustained hypertension (mean supine blood pressure $167 / 104 \mathrm{mmHg}$ ). The effect of treatment on the supine, erect, and post-exercise blood pressure was studied.

After four weeks of therapy, each of the active treatments was significantly superior to treatment with placebo. There was a trend for treatment with practolol alone to reduce the blood pressure more than bendrofluazide alone in all positions but this was not statistically significant after four weeks of treatment. The maximum reduction in supine blood pressure was achieved with combined therapy of practolol with bendrofluazide (mean blood pressure $138.9 / 90.5 \mathrm{mmHg}$ ). The combined therapy was significantly superior to bendrofluazide alone in all positions but was superior to practolol alone only for supine and erect systolic blood pressures. The reductions in blood pressure achieved during the period on combined therapy were not significantly greater than the sum of the reductions obtained in the periods when the individual drugs were given separately.

This study shows that practolol either alone or in combination with bendrofluazide is a useful addition to the range of antihypertensive drugs.

The value of practolol in the treatment of hypertension has not been clearly established though there is evidence that reductions in blood pressure may be obtained using doses ranging from 75$3000 \mathrm{mg} /$ day (Leishman et al., 1970; Prichard, Boakes, and Day, 1971; Esler and Nestel, 1973).

This paper reports the findings of a study which was designed to compare the effectiveness of practolol, bendrofluazide, and combined therapy of practolol with bendrofluazide in a group of patients with sustained hypertension.

\section{Method}

\section{Selection of patients}

Fifty-seven patients ( 30 men, 27 women) referred for investigation of hypertension were assessed in hospital after I4 days off all drug therapy. The criteria for selection for inclusion in the trial were patients under 65 years of age with a blood urea of less than $40 \mathrm{mg} / \mathrm{r} 00 \mathrm{ml}$, on no other medication, with evidence of sustained hypertension - resting, supine, diastolic pressure persistently above 90 to $95 \mathrm{mmHg}$ (according to age). Patients were excluded if there was evidence of previous

Received 7 January 1974. myocardial infarction, cardiac failure, grade 4 retinopathy (Keith Wagener), diabetes, or gout.

During the 36- to 48-hour admission, supine and erect blood pressures were measured at 4-hourly intervals. In addition the observers in the trial (D.B.G. or J.C.P.) measured the blood pressures with Hawksley randomzero sphygmomanometers on two occasions - on the evening of admission (20.00 to 21.00 hours); and after a Io-hour overnight period of complete bed-rest ( 08.00 to 09.00 hours). On both these occasions the number of I2-inch steps required to produce an increment of standing pulse of 30 beats a minute was determined using electrocardiographic control. The patients were invited to participate in the trial if the morning supine diastolic pressures (D.B.G. or J.C.P.) were over 90 to $95 \mathrm{mmHg}$ and under $105 \mathrm{mmHg}$, and other out-patient and ward readings confirmed persistently raised blood pressure readings. At least 35 blood pressure readings were available for each patient.

A total of 24 patients from the original 57 satisfied the criteria for inclusion in the study. The nature of the trial was explained and all gave their consent. There were I2 men and I2 women, age range 24 to 64 (mean 47.4) years. Before discharge from hospital they were familiarized with a standard sequence of questions about general health and the occurrence and severity of a number of symptoms. The methods of access to the doctors conducting the study were also outlined. 


\section{Conduct of trial}

A double-blind crossover method was used to assess the effects on blood pressure of four separate treatments, in each case given twice daily - (I) practolol $200 \mathrm{mg}$ and bendrofluazide placebo; (2) bendrofluazide $2.5 \mathrm{mg}$ and practolol placebo; (3) practolol $200 \mathrm{mg}$ with bendrofluazide $2.5 \mathrm{mg}$; (4) and practolol placebo and bendrofluazide placebo ( 08.00 and 18.00 hours). Separate matching placebo tablets were supplied for both practolol (I.C.I. Ltd.) and for bendrofluazide (Leo Laboratories). Each treatment was given for a four-week period and each patient received the four treatments. The order of administration in each patient was determined by a prearranged design in which each of the 24 possible permutations of the four treatments appeared once and this ensured that in the course of the study on 24 patients each treatment period followed or preceded any other treatment period on six occasions. The drug supplies for each patient were prepacked and new containers (A and B) were issued at the start of each new treatment period $(\mathrm{I} \rightarrow 4)$.

Throughout the study blood pressures were measured using Hawksley random-zero instruments. The mean of 2 to 3 readings of blood pressure (same arm), after 3 to 5 minutes supine and after 2 to 3 minutes erect, was recorded. A single reading was taken after the performance of the predetermined exercise load specified for each patient. The diastolic end-point was taken as the phase-4 muffle. Within observer comparisons of blood pressure readings were made at intervals throughout the trial. The readings on entry to the trial were taken as those recorded at the first visit to the trial clinic after discharge from hospital (maximum 6 days).

The patients were seen at 2-weekly intervals and the blood pressure measurements of any individual patient were recorded under standard conditions at the same time of day, by the same observer (D.B.G. or J.C.P.) except on a few occasions when a deputy substituted (A.G.B.). The observer not recording the blood pressure completed the questionnaire on symptoms in another room. The tablet counts and weights were also recorded. Separate forms were completed by each observer at each of the eight visits. The data were collected on forms specially designed for directed trans- ference to punch cards, so that the statistical analysis could be largely handled by computer.

\section{Results}

A complete set of observations was available for each of the 24 patients. There were no defaulters. The tablet counts were satisfactory throughout $(>90 \%)$.

\section{Blood pressure}

The supine, erect, and post-exercise systolic and diastolic blood pressure readings on entry to the trial and after two and four weeks' treatment with placebo, practolol, bendrofluazide, and practololbendrofluazide are shown in Table $I$.

The mean supine blood pressures of the 24 patients on entry to the trial was $166.8 / 104.0 \mathrm{mmHg}$. There were no statistically significant differences between the blood pressure readings on entry to the trial and the readings in the placebo period.

There were no statistically significant differences between the blood pressure readings after two and four weeks of treatment for any of the four types of treatment except in two situations. These were after two weeks of treatment when lower readings with practolol alone for post-exercise diastolic pressures $(P<0.05)$ and higher readings with combined therapy of practolol with bendrofluazide for erect systolic pressures $(\mathbf{P}<0.0 \mathrm{I})$ were observed.

\section{Comparison of treatments}

The effect of each of the four treatment periods is shown in the Fig. The maximum effect on supine blood pressure was achieved with combined therapy of practolol with bendrofluazide which reduced the blood pressure by $27.9 / 13.5 \mathrm{mmHg}$. The statistical comparison is summarized in Table 2.

The comparison of practolol alone with placebo was always statistically significant. The comparison

TABLE I Mean blood pressures-supine, erect, and post-exercise-after two and four weeks of treatment

\begin{tabular}{|c|c|c|c|c|c|c|c|}
\hline & \multirow[b]{2}{*}{ Weeks } & \multicolumn{2}{|l|}{ Supine } & \multicolumn{2}{|l|}{ Erect } & \multicolumn{2}{|c|}{ Post exercise } \\
\hline & & Systolic & Diastolic & Systolic & Diastolic & Systolic & Diastolic \\
\hline Entry to trial & & $166 \cdot 8$ & $104 \cdot 0$ & $159 \cdot 8$ & $106 \cdot 6$ & $179 \cdot 5$ & $102 \cdot 2$ \\
\hline Placebo & & $\begin{array}{l}163.0 \\
165.7\end{array}$ & $\begin{array}{l}102 \cdot 0 \\
104.8\end{array}$ & $\begin{array}{l}159 \cdot 9 \\
161 \cdot 6\end{array}$ & $\begin{array}{l}108 \cdot 8 \\
108 \cdot 0\end{array}$ & $\begin{array}{l}172 \cdot 4 \\
175.5\end{array}$ & $\begin{array}{l}101 \cdot 1 \\
103 \cdot 3\end{array}$ \\
\hline Practolol & & $\begin{array}{l}\mathrm{I} 47 \cdot 3 \\
\mathrm{I} 48 \cdot 0\end{array}$ & $\begin{array}{l}92 \cdot 7 \\
94 \cdot 4\end{array}$ & $\begin{array}{l}141 \cdot 8 \\
138 \cdot 4\end{array}$ & $\begin{array}{l}95 \cdot 7 \\
95 \cdot 8\end{array}$ & $\begin{array}{l}149 \cdot 3 \\
151 \cdot 2\end{array}$ & $\begin{array}{l}90.5 \\
94.6\end{array}$ \\
\hline Thiazide & 2 & $\begin{array}{l}154.6 \\
150 \cdot 0\end{array}$ & $\begin{array}{l}98 \cdot 7 \\
96 \cdot 0\end{array}$ & $\begin{array}{l}145.8 \\
143.4\end{array}$ & $\begin{array}{l}99 \cdot 8 \\
98 \cdot 8\end{array}$ & $\begin{array}{l}162 \cdot 1 \\
159 \cdot 9\end{array}$ & $\begin{array}{l}96 \cdot 6 \\
96 \cdot 7\end{array}$ \\
\hline $\begin{array}{l}\text { Practolol } \\
\quad+\text { thiaxide }\end{array}$ & $\left\{\begin{array}{l}2 \\
4\end{array}\right.$ & $\begin{array}{l}140 \cdot 1 \\
138.9\end{array}$ & $\begin{array}{l}91 \cdot 6 \\
90 \cdot 5\end{array}$ & $\begin{array}{l}133.5 \\
127.7\end{array}$ & $\begin{array}{l}95 \cdot 3 \\
93 \cdot 4\end{array}$ & $\begin{array}{l}143 \cdot 6 \\
144.0\end{array}$ & $\begin{array}{l}93 \cdot 3 \\
91 \cdot 3\end{array}$ \\
\hline
\end{tabular}



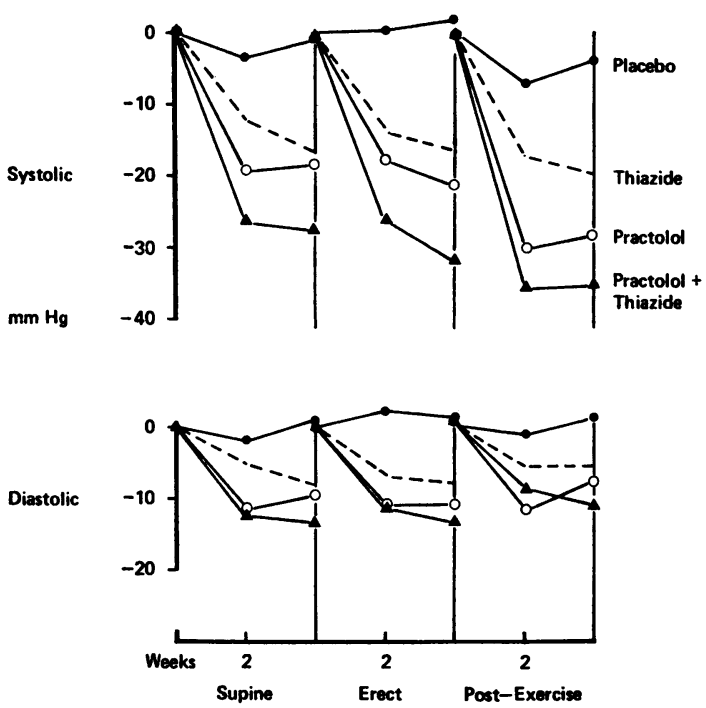

FIG. Effects of placebo, bendrofluazide, practolol, and practolol-bendrofluazide on supine, erect, and post-exercise systolic and diastolic blood pressures after two and four weeks of treatment.

of bendrofluazide alone with placebo was statistically significant except on resting and post-exercise diastolic pressures after two weeks of treatment with bendrofluazide.

The comparison of practolol alone with bendrofluazide alone showed no statistically significant differences except for lower supine diastolic and post-exercise systolic and diastolic pressures after two weeks of treatment with practolol.

Combined therapy of practolol with bendro- fluazide was more effective than practolol alone in three situations - after two weeks of treatment on erect systolic pressure and after four weeks of treatment on supine and erect systolic pressures. The combination of practolol with bendrofluazide was more effective than bendrofluazide alone in all positions after two and four weeks of treatment except on erect and post-exercise diastolic pressures after two weeks of treatment. The reductions in blood pressure achieved during the period on the combined therapy of practolol with bendrofluazide were not statistically different from the sum of the reductions obtained in the periods when the individual drugs were given separately, except on erect diastolic pressures after treatment for two weeks $(\mathbf{P}<0.025)$ and four weeks $(\mathbf{P}<0.05)$.

Reduction of both supine systolic and diastolic blood pressure levels to less than $150 / 90 \mathrm{mmHg}$ was achieved after four weeks of therapy in 14 patients on combined therapy of practolol with bendrofluazide, in II patients on therapy with practolol alone, and in 6 patients on therapy with bendrofluazide alone.

The results were analysed to ascertain if carryover effects from previous treatment periods were present. Analysis of variance showed that overall there were no statistically significant effects.

Examination of the results showed that there was a trend for the mean blood pressure to decrease as the trail progressed (period $\mathrm{I} \rightarrow 4$ ), but this became statistically significant only for the post-exercise diastolic blood pressures $(P<0.05)$.

\section{Weights}

The average initial weight of the patients was $64.3 \mathrm{~kg}$. The average weight loss during the fourmonth trial was $\mathrm{I} \cdot 5 \mathrm{~kg}$ per patient.

TABLE 2 Comparison of treatments (P values) after two and four weeks of therapy

\begin{tabular}{|c|c|c|c|c|c|c|c|c|}
\hline \multicolumn{2}{|c|}{ Comparison of treatments } & \multirow[b]{2}{*}{ Weeks } & \multicolumn{2}{|l|}{ Supine } & \multicolumn{2}{|l|}{ Erect } & \multicolumn{2}{|c|}{ Post exercise } \\
\hline & & & Systolic & Diastolic & Systolic & Diastolic & Systolic & Diastolic \\
\hline Practolol & v Placebo & & $\begin{array}{l}<0.01 \\
<0.001\end{array}$ & $\begin{array}{l}<0.001 \\
<0.001\end{array}$ & $\begin{array}{l}<0.001 \\
<0.001\end{array}$ & $\begin{array}{l}<0.001 \\
<0.001\end{array}$ & $\begin{array}{l}<0.001 \\
<0.001\end{array}$ & $\begin{array}{l}<0.001 \\
<0.001\end{array}$ \\
\hline Thiazide & v Placebo & & $\begin{array}{l}<0.05 \\
<0.001\end{array}$ & $\begin{array}{c}\text { NS } \\
<0.001\end{array}$ & $\begin{array}{l}<0.001 \\
<0.001\end{array}$ & $\begin{array}{l}<0.001 \\
<0.001\end{array}$ & $\begin{array}{l}<0.01 \\
<0.002\end{array}$ & $\begin{array}{c}\text { NS } \\
<0.01\end{array}$ \\
\hline Practolol & $\begin{array}{l}\text { v Thiazide } \\
\int \text { v Practolol }\end{array}$ & $\begin{array}{l}\left\{\begin{array}{l}2 \\
4\end{array}\right. \\
\left\{\begin{array}{l}2\end{array}\right.\end{array}$ & $\begin{array}{l}<0.10 \\
\text { NS } \\
<0.10 \\
<0.05\end{array}$ & $\begin{array}{c}<0.02 \\
N S \\
N S \\
<0.10\end{array}$ & $\begin{array}{c}\text { NS } \\
\text { NS } \\
<0.05 \\
<0.02\end{array}$ & $\begin{array}{c}<0.10 \\
\text { NS } \\
\text { NS } \\
\text { NS }\end{array}$ & $\begin{array}{c}<0.002 \\
<0.10 \\
\text { NS } \\
\text { NS }\end{array}$ & $\begin{array}{l}<0.05 \\
\text { NS } \\
\text { NS } \\
\text { NS }\end{array}$ \\
\hline $\begin{array}{l}\text { Practolol } \\
\quad+\text { thiazide }\end{array}$ & $\left\{\begin{array}{l}\text { v Thiazide } \\
\text { v Placebo }\end{array}\right.$ & $\left\{\begin{array}{l}2 \\
4 \\
2 \\
4\end{array}\right.$ & $\begin{array}{l}<0.001 \\
<0.02 \\
<0.001 \\
<0.001\end{array}$ & $\begin{array}{l}<0.01 \\
<0.05 \\
<0.001 \\
<0.001\end{array}$ & $\begin{array}{l}<0.001 \\
<0.001 \\
<0.001 \\
<0.001\end{array}$ & $\begin{array}{l}<0.10 \\
<0.05 \\
<0.001 \\
<0.001\end{array}$ & $\begin{array}{l}<0.001 \\
<0.001 \\
<0.001 \\
<0.001\end{array}$ & $\begin{aligned} & N S \\
&<0.05 \\
&<0.01 \\
&<0.001\end{aligned}$ \\
\hline
\end{tabular}




\section{Symptom inquiry}

The analysis of the questionnaire showed minor variations between treatments with placebo, practolol, bendrofluazide, and combined therapy of practolol with bendrofluazide. There were similar patterns of general health, postural hypotension, headaches, mood, sleep, dreams, dyspepsia, appetite, heartburn, vomiting, taking of antacids, bowel habit, and nocturia. There was a slight increase in the occurrence of polyuria in the group of patients when on treatment with bendrofluazide or on the combined therapy of practolol with bendrofluazide.

\section{Discussion}

The study shows that practolol, $400 \mathrm{mg} / \mathrm{day}$ was as effective as bendrofluazide, $5 \mathrm{mg} /$ day in lowering supine, erect, and post-exercise systolic and diastolic blood pressures in patients with mild hypertension. After two weeks of treatment practolol significantly lowered blood pressure in all positions in comparison with placebo, in contrast to bendrofluazide which did not produce significant reduction in supine and post-exercise diastolic pressures. The combination of practolol with bendrofluazide achieved a satisfactory reduction in blood pressure to a mean supine blood pressure of $139 / 91 \mathrm{mmHg}$. The combination was better than practolol alone only in the reduction of supine and erect systolic blood pressures but was superior to bendrofluazide alone in all positions after four weeks of therapy. There was no evidence of interaction (synergism) between practolol and bendrofluazide as the effects of the drugs in combination were not significantly greater than the sum of the effects of the individual drugs given separately.

The criteria for patient selection appear to have been satisfactory for the purposes of the study because blood pressures on entry to the trial were not statistically different from readings in the placebo period. In addition there was no statistically significant fall in the mean blood pressures for each period $(I \rightarrow 4)$ as the trial progressed. Nevertheless there was a trend for the mean period blood pressures to fall and this may be related to several factors including further familiarization with the trial routine, overall weight loss of the group of patients, and, in the case of post-exercise blood pressures, to increased experience and training with the specified exercise load for each patient. The number of patients excluded from the trial because of the strict selection routine suggests that many patients are being treated, and perhaps included in clinical trials, who do not have sustained hypertension.

The design of the trial and the standardized methods of measurement differ from the everyday management of hypertension, but elimination of observer and patient bias is essential if reliable baseline results are to be obtained. The findings refer to patients under the conditions of the trial and may differ from reductions in blood pressure which may be observed under less strict conditions.

The doses of practolol and bendrofluazide were chosen on the basis of dose-finding studies (R. A. Wiseman, 1973, personal communication). Fixed dose studies have disadvantages because of individual variation in response between patients. Nevertheless, such studies are of interest to determine the effect of the selected dose in reducing blood pressure in a group of patients over a specific time scale and to ascertain the intervals at which increments in dosage should be made. A rapid increase in dosage may conceal unexpected responses which may be obtained with lower doses because the hypotensive effect of the drug or its metabolites may not correspond to the calculated half-life of the drug. This study shows that there was a trend in some instances for a reduction in blood pressure to occur in the interval between the two- and fourweek readings, but only the further reduction in the erect systolic pressure during combined therapy of practolol with bendrofluazide reached a level of statistical significance. Since the analysis of variance shows that overall there were no carry-over effects due to the influence of previous treatments, the results suggest that further increments in the dose of practolol may be made after a 2-week interval. The reduction in blood pressure achieved with bendrofluazide is slower in onset, but this is not of importance in the control of mild hypertension though it may have more significance in the treatment of moderate or severe hypertension when therapy in combination with other antihypertensive agents is planned. Further studies are required to determine the respective hypotensive effects of practolol and bendrofluazide over longer intervals, both at fixed and variable doses.

The results of standard questionnaires about symptoms must always be interpreted with caution even if they are completed by the same observers who are unaware of the current treatment or blood pressure status. Nevertheless the occurrence of symptoms in the patients on entry to the trial and during the treatment with placebo was of a similar incidence as during treatment with other drugs, except for polyuria. This a reminder that adverse symptoms are not always attributable to drug therapy.

We wish to thank all who helped in this study, in particular Dr. R. A. Wiseman and Mr. J. A. Lewis of I.C.I. Ltd., and Dr. R. A. Wood, consultant physician, Perth Group of Hospitals. 


\section{References}

Esler, M. D., and Nestel, P. J. (1973). Evaluation of practolol in hypertension. Effects on sympathetic nervous system and renin responsiveness. British Heart fournal, 35, 469.

Leishman, A. W. D., Thirkettle, J. L., Allen, B. R., and Dixon, R. A. (1970). Controlled trial of oxprenolol and practolol in hypertension. British Medical Fournal, 4, 342.
Prichard, B. N. C., Boakes, A. J., and Day, G. (1971). Practolol in the treatment of hypertension. Postgraduate Medical Fournal, 47, January Suppl., 84.

Requests for reprints to Dr. J. C. Petrie, Department of Therapeutics and Clinical Pharmacology, University of Aberdeen, University Medical Buildings, Forsterhill, Aberdeen AB9 2ZD. 